\title{
Site Selection \& Configuration for Pumped Storage Power Plants
}

\author{
M.T.A.P. Wickramarathna \\ BSc Eng. (Hons) (Moratuwa), MSc (Moratuwa), MSc (Sweden), C.Eng., MIE (SL), Member SLEMA \\ Electrical Engineer, Ceylon Electricity Board
}

\begin{abstract}
Sri Lanka is currently developing coal fired power plants. Currently one coal power plant is in operation with an installed capacity of 3 units each of $300 \mathrm{MW}$. The Long Term Generation Plan 2013-2032, indicates that there will be 14 new coal power generating units to be introduced to the power system in future.
\end{abstract}

In Sri Lanka, the electricity demand rapidly varies with time. The daily load curve shows a minimum of 1,000 MW at off-peak, and 2,150 MW at peak. Such rapid variations cause base load coal power plants to be operated with lower efficiency during low demand hours. Such situations create an opportunity for storage mechanisms. Pumped storage power plants (PSPPs) is one of such storage power plant that could be deployed in Sri Lanka. The country's natural geography is suitable to facilitate nearly 5,000MW of PSPPs and some attractive sites have already been identified. Most importantly, some of them can be designed as the Pumped Storage Power Plant Complexes (PSPPC). A common large upper pond or lower pond can be utilized by two or more lower ponds or upper ponds forms a PSPPC. The economic viability of having PSPPs in Sri Lanka can improve with such PSPP complexes. This paper discusses the basic design principles of proposed PSPPs and PSPPCs in Sri Lanka.

\section{Introduction}

Not only that country's economy depends on electricity supply; Sri Lanka has reached the national electrification ratio of $99.5 \%$ by now. The maximum demand is around 2164MW while the installed capacity is 3362MW (Statistical Digest 2013, CEB).Sri Lanka has to run expensive thermal power in the peak demand time. At present, Sri Lanka has $900 \mathrm{MW}$ coal power plants but cannot run them efficiently at full load during late night off-peak time and some hours during the day, too.

In year 2013, peak demand is around 2,150MW while off peak is around 1,000MW. This off-peak demand is maintained by the utility by giving special off-peak tariffs for medium and large customer. The off-peak tariff is Rs. 5.90 while peak tariff is Rs. 23.50 for Industrial-3 customers. That means peak tariff is four times the off-peak tariff; both figures do not reflect the actual cost electricity. By reducing the peaks of the load curve using PSPP, Sri Lanka may be able to produce cheap electricity, while giving actual cost reflective, lower tariff to customers.

Attractive sites have been identified for PSPP; along Kiriketi Oya in Haputale; Halgran Oya in Hanguranketha; Maha Oya, Kuda Oya, Mal Oya \& GurugalOya in Gampola and Dambagastalawa Oya in Nuwara Eliya. Most importantly, some of them can be designed as the Pumped Storage Power Plant Complexes. A common large upper pond or lower pond can be utilized by two or more lower ponds or upper ponds, to form a PSPP complex.

\section{Establishment of Criteria to Locate a Project Site}

Table 1 shows the criteria used for determining the sites of PSPPs in a reconnaissance study, and their expected status. For example, the selected site should be suitable for the construction of a power plant of more than $250 \mathrm{MW}$ in capacity and should run for six hours during the period of higher demand each day.

\section{Selecting Sites for PSPPs}

The suitable sites were searched using the 1:50,000 scale topographical maps. Basically, natural location for the reservoir and dam with adequate reservoir volume with minimum environment \& social effects (avoiding forests, natural parks, historical \& cultural heritage sites, areas with high population density) and the locations which has $\mathrm{L} / \mathrm{H}$ ratio less than 12 were considered. Detailed Analysis comprising basic design and the calculation, was done for the selected sites, using 1:10,000 scale topographical maps. The following table shows the basic details of the selected sites for PSPP.

The locations and design parameters for the four PSPPs each with 500MW capacity, namely Kiriketi I, Keriketi II, Keriketi II and Halgran PSPPs were discussed in Planning of Pumped Storage Power Plants for Power Generation in Sri Lanka, SLEMA Journal Volume 14 No.2 September 2011.

This paper discusses the details of locations and design parameters of remaining PSPP sites. 
Table 1 - Criteria for Pumped Storage Power Project Locations in Sri Lanka

\begin{tabular}{|c|c|c|c|}
\hline \multirow{12}{*}{ Technical } & Issue & Item & Criteria status \\
\hline & Generation & -Peak duration time & $-6 \mathrm{hrs}$ \\
\hline & Plan & -Installed Capacity & -More than $250 \mathrm{MW}$ \\
\hline & $\begin{array}{l}\text { Limit of } \\
\text { manufacturing } \\
\text { of power facility }\end{array}$ & $\begin{array}{l}\text {-Design Head } \\
\text {-Max. utilizing water depth } \\
\text { of pond }\end{array}$ & $\begin{array}{l}\text {-More than } 350 \mathrm{~m} \text { of maximum head } \\
\text {-Less than } 75 \mathrm{~m}\end{array}$ \\
\hline & \multirow[t]{6}{*}{$\begin{array}{l}\text { Location/ } \\
\text { Layout }\end{array}$} & -Catchment area & $\begin{array}{l}\text {-More than } 5 \mathrm{~km}^{2} \text { (total } \\
\text { of upper, lower dams diverted ) }\end{array}$ \\
\hline & & -Dam crest length & -Less than 500m \\
\hline & & -Dam height & -Less than $180 \mathrm{~m}$ \\
\hline & & -Length of water way & -Less than $10 \mathrm{Km}$ \\
\hline & & $-\mathrm{L} / \mathrm{H}$ ratio & -Less than 12 \\
\hline & & $\begin{array}{l}\text {-Over burden of } \\
\text { underground power cavern }\end{array}$ & -Less than $1020 \mathrm{~m}$ \\
\hline & & -Active fault & $\begin{array}{l}\text {-Avoid the zone of active faults and those } \\
\text { Quaternary Era }\end{array}$ \\
\hline & $\begin{array}{l}\text { Geological } \\
\text { conditions }\end{array}$ & $\begin{array}{l}\text {-Base rock conditions } \\
\text { especially for underground } \\
\text { power cavern }\end{array}$ & $\begin{array}{l}\text {-Avoid the area of Quaternary Era and } \\
\text { weak and unconsolidated strata }\end{array}$ \\
\hline \multirow[t]{3}{*}{$\begin{array}{l}\text { Environm } \\
\text {-ental }\end{array}$} & Natural & $\begin{array}{l}\text {-Protected Area (e. g. Nature } \\
\text { Reserves) } \\
\text {-Endangered species }\end{array}$ & $\begin{array}{l}\text {-Beyond the confines of protected Areas } \\
\text { (Natural Parks and reserves) } \\
\text {-Avoid the critical habitats } \\
\text { of important fauna and flora }\end{array}$ \\
\hline & \multirow[t]{2}{*}{ Social } & -Mining right & -Avoid the area of mining concession \\
\hline & & $\begin{array}{l}\text {-Historical and Cultural } \\
\text { heritage } \\
\text {-House to be submerged }\end{array}$ & $\begin{array}{l}\text {-Avoid being submerged } \\
\text {-Necessary to consider }\end{array}$ \\
\hline
\end{tabular}

Table 2 - Summary of Candidate PSPP

\begin{tabular}{|c|c|c|c|c|c|c|c|}
\hline \multirow{3}{*}{ No. } & \multirow{3}{*}{$\begin{array}{l}\text { Name of the } \\
\text { Pumped } \\
\text { Storage }\end{array}$} & \multirow{3}{*}{$\begin{array}{c}\text { Name of the } \\
\text { Pumped Storage } \\
\text { Plant }\end{array}$} & \multicolumn{4}{|c|}{ Project Feature } & \multirow{3}{*}{$\begin{array}{l}1: 50,000 \\
\text { Map No }\end{array}$} \\
\hline & & & Capacity & Length & $\begin{array}{l}\text { Rough } \\
\text { Height }\end{array}$ & Ratio & \\
\hline & & & $(\mathrm{MW})$ & $\mathrm{L}(\mathrm{m})$ & $\mathrm{H}(\mathrm{m})$ & $\mathrm{L} /$ & \\
\hline 1 & \multirow[t]{2}{*}{ Maha PSPP } & Uduwella PSPP & 500 & 4,110 & 410 & 10.0 & 61 \\
\hline 2 & & Alugolla PSPP & 500 & 3,890 & 510 & 7.6 & 61 \\
\hline 3 & \multirow[t]{2}{*}{ KMG PSPP } & Mul PSPP & 250 & 4,510 & 400 & 11.3 & 61 \\
\hline 4 & & Gurugal PSPP & 500 & 5,320 & 650 & 8.2 & 61 \\
\hline 5 & & $\begin{array}{l}\text { Puna-Kotmale } \\
\text { PSPP }\end{array}$ & 500 & 6,570 & 700 & 9.4 & 61 \\
\hline 6 & & $\begin{array}{l}\text { Dambagastalawa } \\
\text { PSPP }\end{array}$ & 300 & 2,840 & 470 & 6.0 & 68 \\
\hline 7 & & Agra PSPP & 300 & 3,640 & 330 & 11.0 & 68 \\
\hline
\end{tabular}

\section{Maha Pumped Storage Power Plant Complex}

The project is to be situated on the Maha Oya, in the Gampola area, No. 61, 1:50,000 map. There are two options for the Upper Pond.
The two Upper Ponds are in Kandy district, Central Province and Lower Pond is in Kegalla district, Sabaragamuwa Province. Travelling distance is $90 \mathrm{~km}$ from Colombo on the ColomboKandy road. The principal features of the Project; 
Table 3 - Summary of Basic Design Configuration of Maha PSPP Complex

\begin{tabular}{|c|c|c|c|}
\hline & Maha PSPP Complex & Uduwella PSPP & Alugolla PSPP \\
\hline \multirow{4}{*}{$\begin{array}{l}\text { Project } \\
\text { Specification }\end{array}$} & Installed Capacity P (MW) & 500 & 500 \\
\hline & Designed Discharge $Q\left(\mathrm{~m}^{3} / \mathrm{s}\right)$ & 152 & 121 \\
\hline & Effective Head $\mathrm{H}_{\mathrm{e}}(\mathrm{m})$ & 387.6 & 485.2 \\
\hline & Peak Duration Hours & 6 & 6 \\
\hline \multirow[t]{7}{*}{ Upper Reservoir } & Dam Type & Rock Fill & Concrete Gravity \\
\hline & Dam Height (m) & 32 & 41 \\
\hline & Crest Length $(\mathrm{m})$ & 340 & 260 \\
\hline & Reservoir Volume at FSL ( Mil m3) & 3.38 & 2.6 \\
\hline & H.W.L (m) & 714 & 814 \\
\hline & L.W.L (m) & 694.45 & 785 \\
\hline & Usable Water Depth (m) & 19.55 & 29 \\
\hline \multirow[t]{8}{*}{ Lower Reservoir } & Dam Type & \multicolumn{2}{|c|}{ Concrete Gravity } \\
\hline & Dam Height $(\mathrm{m})$ & \multicolumn{2}{|l|}{57} \\
\hline & Crest Length $(\mathrm{m})$ & \multicolumn{2}{|l|}{350} \\
\hline & Reservoir Volume at FSL ( Mil m3) & \multicolumn{2}{|l|}{5.94} \\
\hline & H.W.L (m) & \multicolumn{2}{|l|}{300} \\
\hline & L.W.L (m) & \multicolumn{2}{|l|}{267.2} \\
\hline & Usable Water Depth (m) & \multicolumn{2}{|l|}{32.8} \\
\hline & Headrace $(\mathrm{m})$ & 1,850 & 2,350 \\
\hline \multirow[t]{2}{*}{ Water way } & Penstock (m) & 2,400 & 1,320 \\
\hline & Tail Race $(\mathrm{m})$ & 200 & 430 \\
\hline Power House & Type & Underground & Underground \\
\hline \multicolumn{2}{|l|}{$\mathrm{L} / \mathrm{H}$} & 10.64 & 7.86 \\
\hline
\end{tabular}

Figure 1 - MAHA Pumped Storage Power Plant Complex in 1:50,000 Map

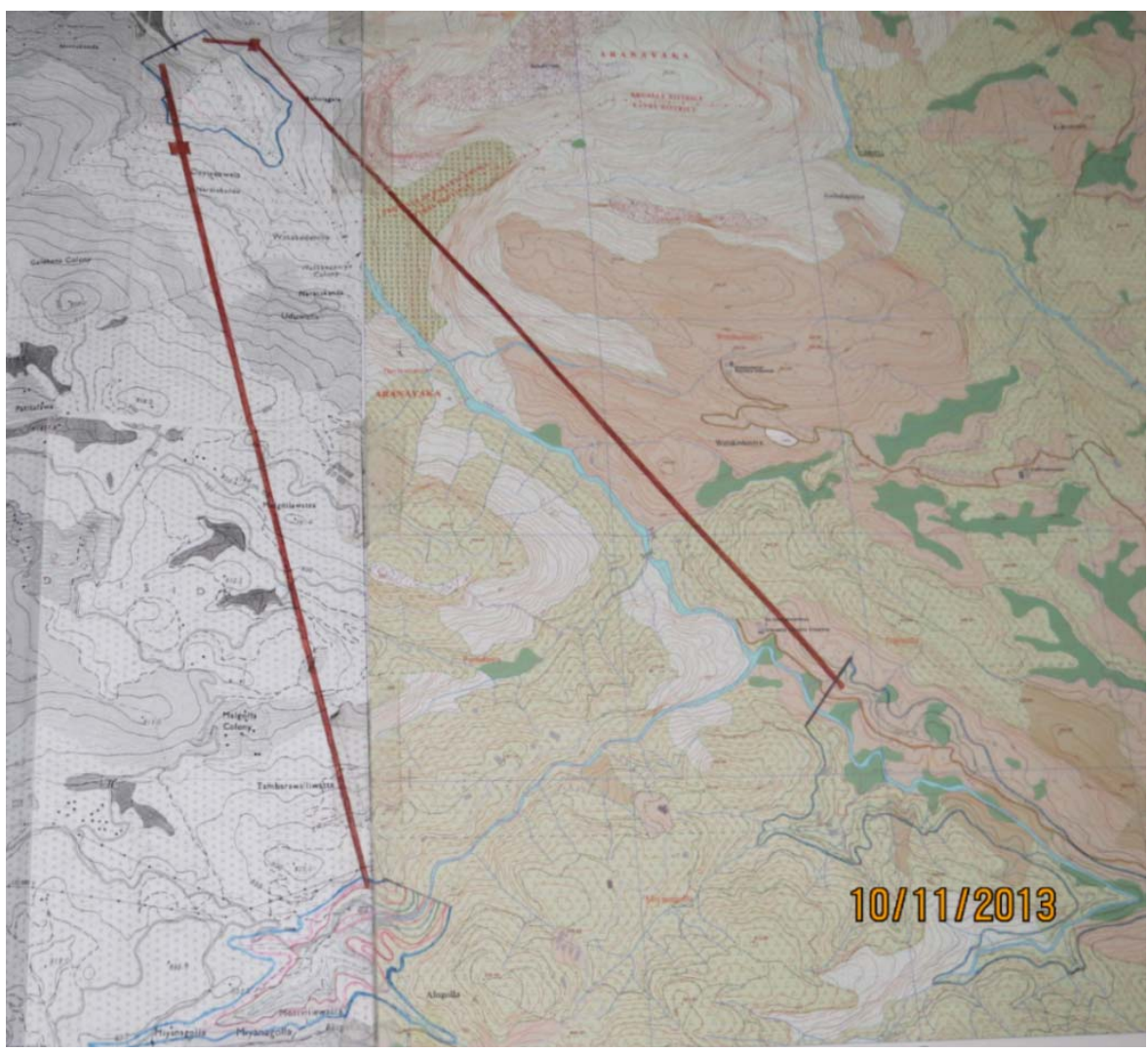




\section{Figure 2 - Waterway Profile of Uduwella Upper Pond to Arama Lower Pond}

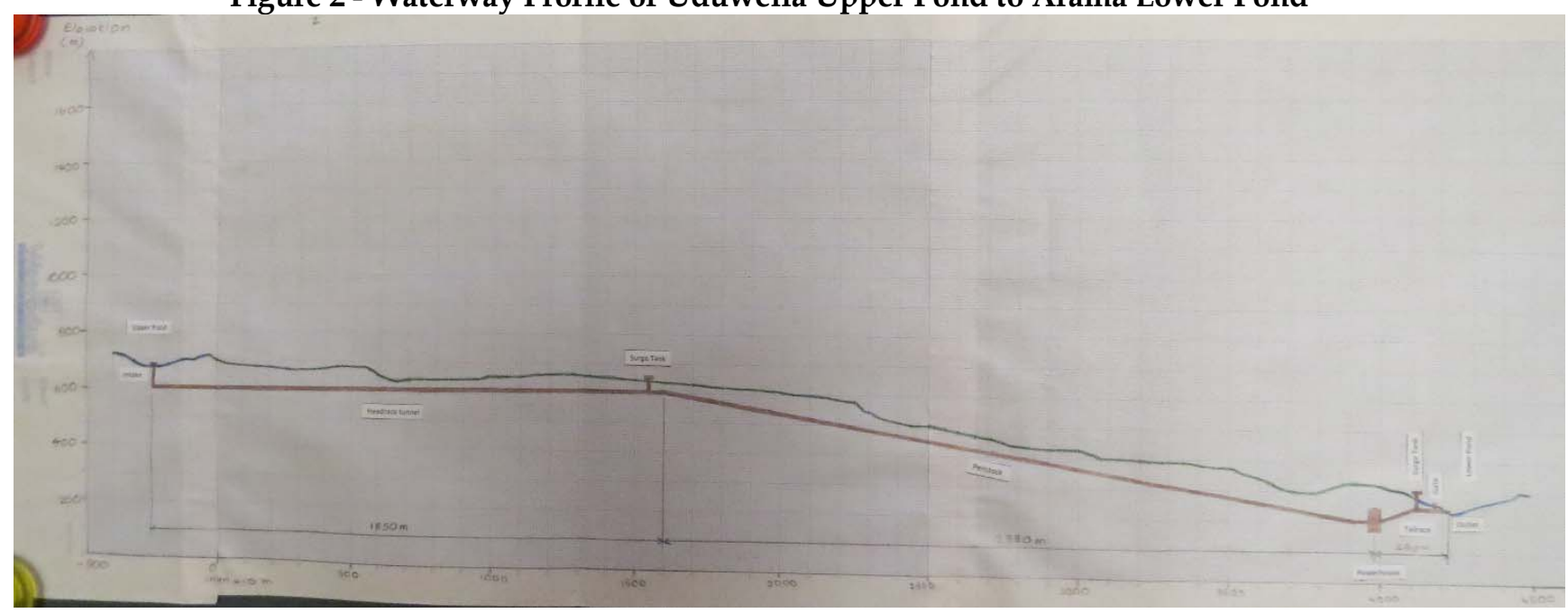

Figure 3 - Waterway Profile of Alugolla Upper Pond to Arama Lower Pond

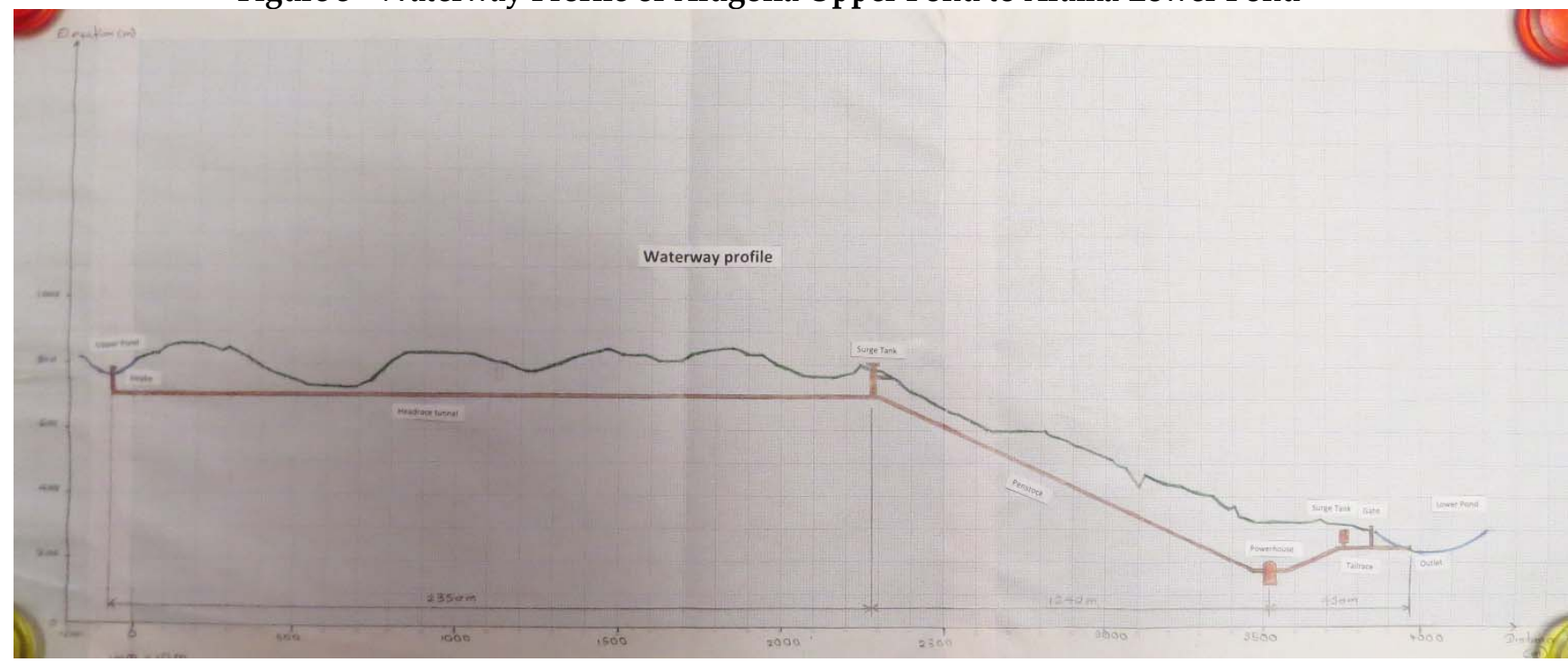

\section{Calculation of Catchment Area}

When the dam site is selected, the watershed is checked using the topographic map.

Catchment Area of "Arama" Lower Pond: $17.725 \mathrm{~km}^{2}$; Catchment Area of "Uduwella" Upper Pond: 4.8754 km²;

Catchment Area of "Alugolla" Upper Pond: $2.725 \mathrm{~km}^{2}$

\section{Preparation of Storage Capacity Curve}

The reservoir area at each elevation is measured with planimeter on a topographic map, and the water storage capacity curves shown in Figure 6, Figure 7and Figure 8 were prepared.

\section{Temporary Fixing of Maximum Plant Discharge}

The maximum plant discharge is obtained by the following equation;

“Uduwella" Upper Pond: $Q \max =\frac{P}{9.8 \times \mathrm{H} x \eta}=$ $\frac{500000 \mathrm{~kW}}{8.5 \times 410}=143.5 \mathrm{~m} 3 / \mathrm{s}$

“Alugolla" Upper Pond: $Q \max =\frac{P}{9.8 \times H \times \eta}=$ $\frac{500000 \mathrm{~kW}}{8.5 \times 510}=115.3 \mathrm{~m} 3 / \mathrm{s}$

where, Qmax : Maximum plant discharge (m3/s); $\mathrm{P}$ : Maximum output $(\mathrm{kW}) ; \mathrm{H}$ : Head (Difference in riverbed elevation between upper and lower dams[1650m-880m]); $\eta$ : Combined efficiency at maximum output

The value $9.8 \times \eta=8.5$ should be used in the study. 


\section{Determination of Storage Capacity of Pond}

The peak duration hour is set at 6 hours to obtain the active storage capacity.

“Uduwella" Upper Pond: $V e=Q \max x T \times 3600$

$$
=143.5 \frac{\mathrm{m} 3}{\mathrm{~s}} \times 6 \mathrm{hrs} x 3600=3,099,600 \mathrm{CM}
$$

"Alugolla" Upper Pond: $V e=Q \operatorname{maxxTx} 3600=$ $115.3 \frac{m 3}{s} x 6$ hrsx $3600=2,491,349$ CM

"Arama" Lower Pond: Ve=QmaxxTx $3600=$ 5,590,949 CM

where, $\mathrm{Ve}=$ Effective storage capacity (m3); $\mathrm{T}=$ Peak duration hours (hr)

Estimation of Sediment Volume and Determination of Sedimentation Level

(1) Estimation of Sediment Volume

The sedimentation level is determined by estimating sedimentation for 100 years. The sediment volume is estimated as follows provided that qs is assumed to be $200 \mathrm{~m}^{3} / \mathrm{km}^{2} /$ year.

$$
V s=q s \times C a(d) \times 100
$$

$=200 \mathrm{~m}^{3} / \mathrm{km}^{2} /$ year $\times 0.4 .87454 \mathrm{~km}^{2} \times 100$ years $=$ 97,508 $\mathrm{m}^{3}$ (Uduwella Upper Pond)

$=200 \mathrm{~m}^{3} / \mathrm{km}^{2} /$ year $\times 2.725 \mathrm{~km}^{2} \times 100$ years $=$

$54,500 \mathrm{~m}^{3}$ (Alugola Upper Pond)

$=200 \mathrm{~m}^{3} / \mathrm{km}^{2} /$ year $\times 17.725 \mathrm{~km}^{2} \times 100$ years $=$ $354,500 \mathrm{~m}^{3}$ (Arama Lower Pond)

where, Vs : Sediment volume for 100 years $\left(\mathrm{m}^{3}\right)$; qs : Specific sediment yield $\left(\mathrm{m}^{3} / \mathrm{km}^{2} /\right.$ year $) ; \mathrm{Ca}(\mathrm{d})$

: Catchment area at dam site $\left(\mathrm{km}^{2}\right)$

(2) Setting of Sedimentation Level

The sedimentation level is obtained based on the reservoir area and storage capacity curve as shown below.

Uduwella Upper Pond: EL 683.25m; Alugola Upper Pond : EL 775.00m; Arama Lower Pond : EL 256.00m

Figure 4 - Setting of Sedimentation Level

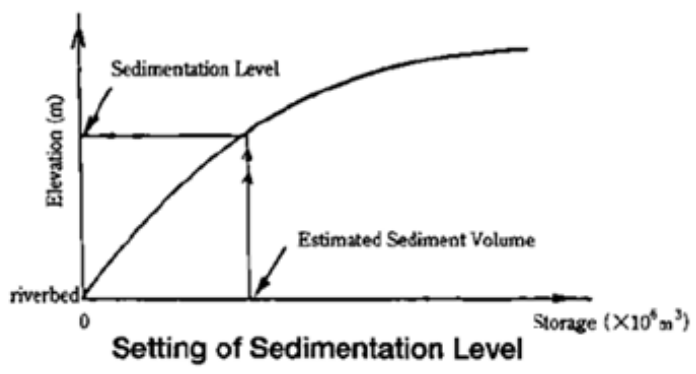

Determination of Water Level (Upper and Lower Ponds)

(1) Low Water Level

The low water level (LWL) is set at a position of about twice the inner diameter (D) of the headrace tunnel above the sedimentation level as shown in Figure 5, to prevent intrusion of air into the tunnel.

Figure 5 - Relation between intake and LWL

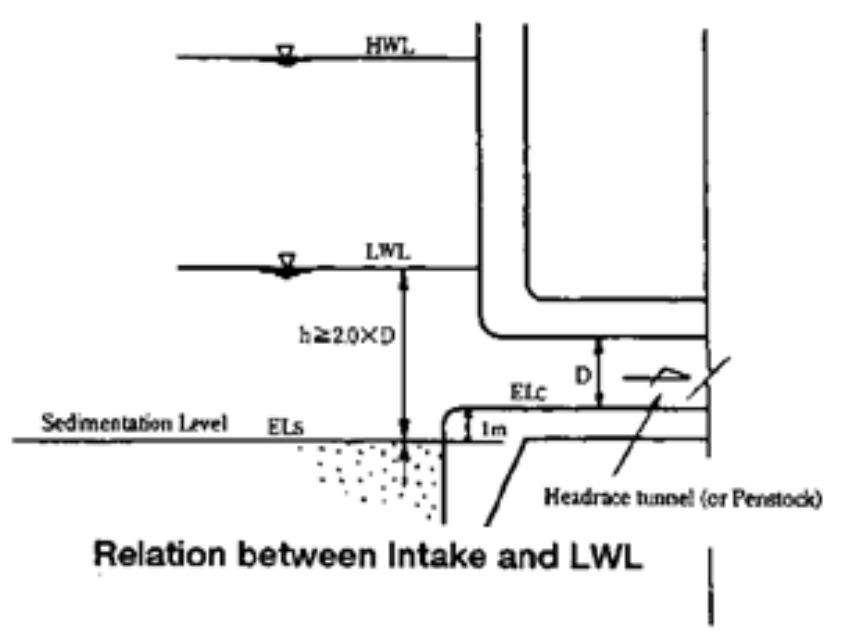

$\mathrm{Q}=\Pi \times \mathrm{D}^{2} / 4 \times 6 \mathrm{~m} / \mathrm{s}$

The tunnel inner diameter is obtained as follows by setting the flow velocity at $6 \mathrm{~m} / \mathrm{s}$.

\section{Uduwella PSPP:}

$\mathrm{D}=(4 \mathrm{Q} / 6 \Pi)^{0.5}=(4 \times 140 / 6 \Pi)^{0.5}=5.6 \mathrm{~m}$

Alugolla PSPP:

$\mathrm{D}=(4 \mathrm{Q} / 6 \Pi)^{0.5}=(4 \times 115 / 6 \Pi)^{0.5}=5.0 \mathrm{~m}$

Where, Q: Plant Discharge $\left(\mathrm{m}^{3} / \mathrm{s}\right) ; \mathrm{D}$ : Diameter of Headrace Tunnel (m)

Thus the low water level (LWL) is calculated as below.

Uduwella Upper Pond: EL 683.25m + 2x5.6 = EL. $694.45 \mathrm{~m}$

Alugolla Upper Pond : EL 775.00m + 2x5.0 = EL. $785.0 \mathrm{~m}$

Arama Lower Pond $\quad$ : EL $256.00 \mathrm{~m}+2 \times 5.6=\mathrm{EL}$. $267.2 \mathrm{~m}$

\section{(2) High Water Level}

The high water level (HWL) is determined by using the storage capacity curves shown in Figure 6, Figure 7, adding the low water level (LWL) to the available drawdown (ha) corresponding to the effective storage capacities are obtained by Eq. $V e=Q \operatorname{maxx} T x 3600$ 
Thus the high water level (HWL) is calculated as below.

Uduwella Upper Pond: LWL $694.45 \mathrm{~m}+$ ha $19.55 \mathrm{~m}=$ HWL 714m

Alugolla Upper Pond : LWL $785.0 \mathrm{~m}+29$ ha $=$ HWL 814m

Arama Lower Pond : LWL $267.2 \mathrm{~m}+$ ha $32.8 \mathrm{~m}=$ HWL 300m

Where, ha : Available drawdown $(\mathrm{m})=19.55 \mathrm{~m}$..... (Uduwella Upper Pond)

$$
\begin{aligned}
& =29 \mathrm{~m} \ldots \ldots . .(\text { Alugolla Upper Pond) } \\
& =32.8 \mathrm{~m} \text {.........(Arama Lower Pond) }
\end{aligned}
$$

Figure 6 - Uduwella Upper Pond - Capacity Curve

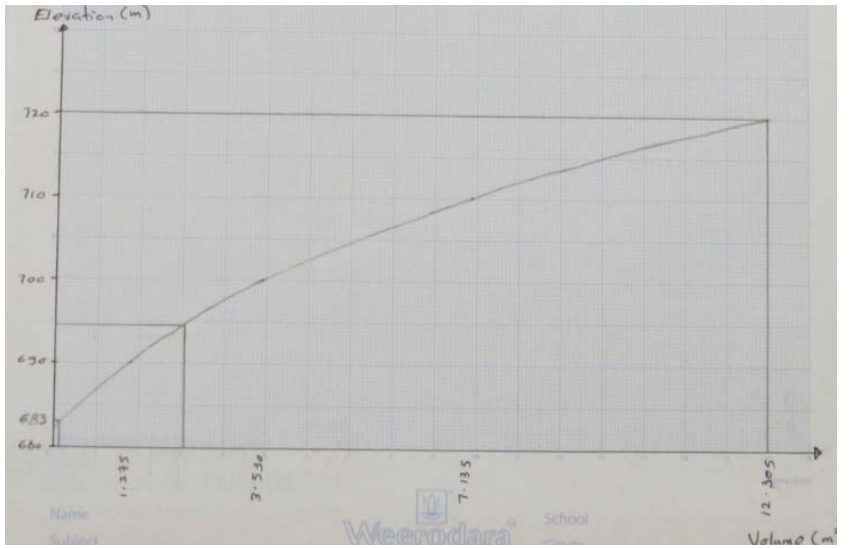

Figure 7 - Alugolla Upper Pond - Capacity Curve

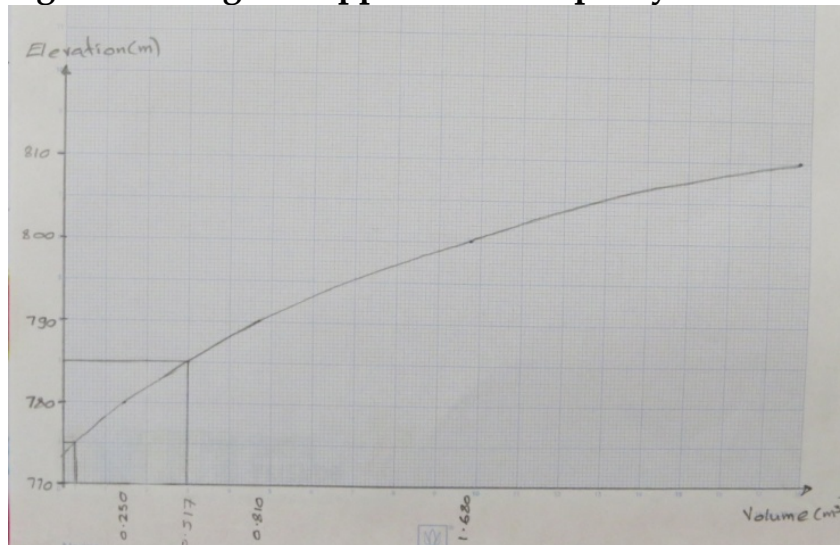

Figure 8 - Arama Lower Pond - Capacity Curve

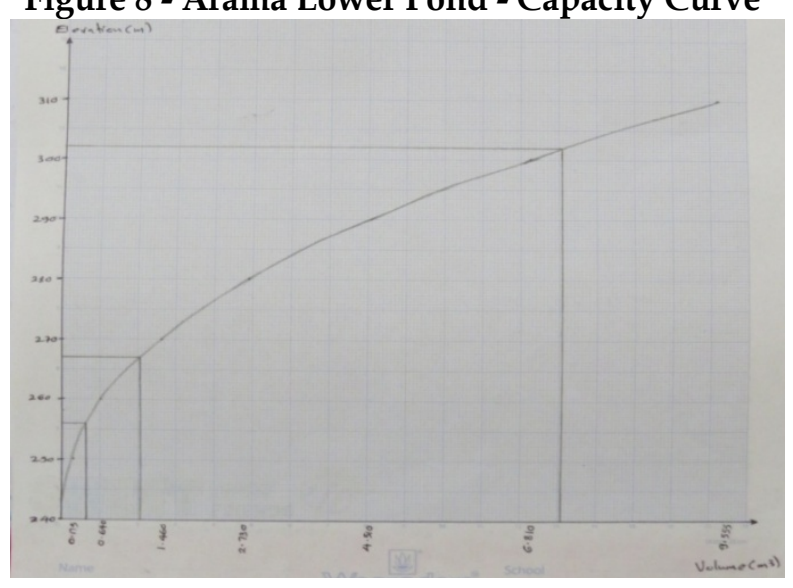

Determination of Normal Intake Water Level and Tailwater Level

The normal intake water level and tailwater level which correspond to mean water levels of both reservoirs are determined by the following equation.

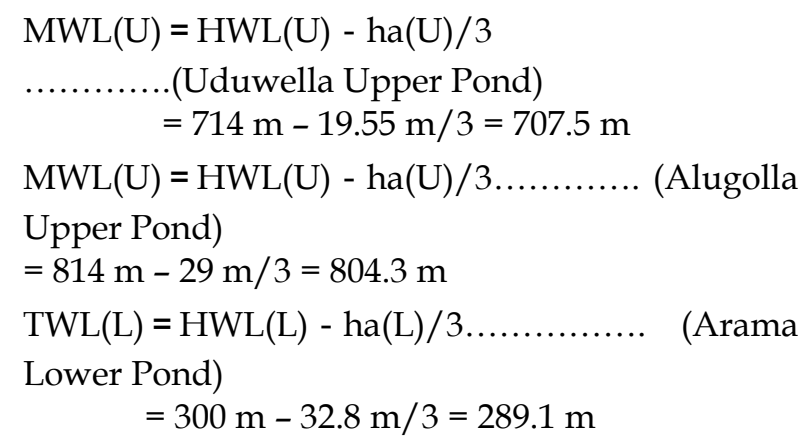

where, HWL, LWL, ha : High water level, low water level and available drawdown (m) of upper pond (U) and lower pond (L), (m); MWL : Normal intake water level (m); TWL : Normal tailwater level (m); ha : Available drawdown (m)

\section{Preparation of Waterway Profile}

(1) Setting the elevation of turbine center

The turbine center is set at the elevation corresponding to the draft head below the low water level of the lower pond as described in the following formula.

\section{For Uduwella PSPP}

Elevation of Turbine Center $=$ LWL (Lower Pond)

- Draft Head (m)

$$
=\text { LWL 267.2m }-56 \mathrm{~m}=\text { EL 211.2m }
$$

\section{For Alugolla PSPP}

Elevation of Turbine Center $=$ LWL (Lower Pond) - Draft Head (m)

Where

$$
=\text { LWL 267.2m - 64m = EL 203.2m }
$$

For Uduwella PSPP - (Head Loss ignored)

Maximum Pumping Head (m): HWL (Upper Pond) - LWL (Lower Pond) + Head Loss $=714 \mathrm{~m}$ $267.2 \mathrm{~m}=446.8 \mathrm{~m}$

For Alugolla PSPP - (Head Loss ignored)

Maximum Pumping Head (m): HWL (Upper Pond) - LWL (Lower Pond) + Head Loss $=814 \mathrm{~m}-$ $267.2 \mathrm{~m}=546.8 \mathrm{~m}$

Draft Head is obtained from the relation between the maximum pumping head and draft head as shown in Figure 9. 
Figure 9 - Relation between the Maximum Pumping Head and Draft Head

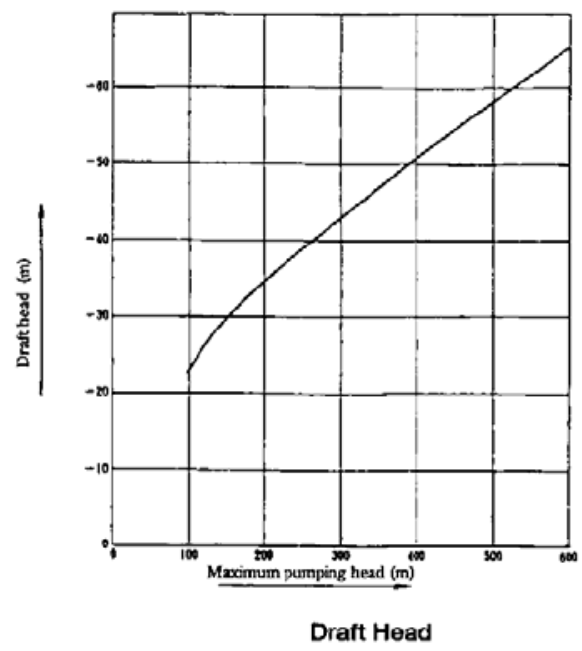

(2) Dam specification and turbine center Dam specifications (HWL and LWL) and the elevation of turbine centre of the power plants are determined as below.

Uduwella Upper Pond: HWL: 714m; LWL: 694.45 m; Available drawdown: $19.55 \mathrm{~m}$

Alugolla Upper Pond: HWL: 814 m; LWL: 785 m; Available drawdown: $29 \mathrm{~m}$

Arama Lower Pond: HWL: 300 m; LWL: 267.2 m; Available drawdown: $32.8 \mathrm{~m}$

Turbine Center for Uduwella PSPP: EL: $211.2 \mathrm{~m}$

Turbine Center for Alugolla PSPP: EL: $203.2 \mathrm{~m}$

\section{Calculation of Head Loss and Effective Head for Uduwella PSPP}

The effective head is calculated on the basis of the following equation;

$$
\begin{array}{ll}
H g=M W L-T W L=H W L-\frac{h a}{3}-T W L & \\
=707.5 m-289.1 m=418.4 m & = \\
H l=a x L 1+b x L 2+c x L 3+\Delta h & = \\
1 / 300 \times 1850+1 / 100 \times 2400+1 / 300 \times 200+3.5 & = \\
30.8 \mathrm{~m} &
\end{array}
$$$$
\mathrm{He}=\mathrm{Hg}-\mathrm{Hl} \quad=418.4-30.8=387.6 \mathrm{~m}
$$

where,

MWL : Normal intake water level $(\mathrm{m})=707.5 \mathrm{~m}$; TWL : Tailwater level $(\mathrm{m})=289.1 \mathrm{~m} ; \mathrm{Hg}$ : Gross head $(\mathrm{m})=418.4 \mathrm{~m}$; Hl : Head loss $(\mathrm{m})=30.8 \mathrm{~m}$; He : Effective head $(\mathrm{m})=387.6 \mathrm{~m}$; L1 : Length of headrace $(\mathrm{m})=1850 \mathrm{~m}$

L2 : Length of penstock $(\mathrm{m})=2400 \mathrm{~m}$; L3 : Length of tailrace $(\mathrm{m})=200 \mathrm{~m} ; \Delta \mathrm{h}$ : Other head losses $(\mathrm{m})$ $=3.5 \mathrm{~m}$

a, b and c : Coefficients to obtain losses; a :Pressure headrace tunnel 1/300; b: Penstock 1/100;

c :Pressure tailrace tunnel 1/300
Calculation of Head Loss and Effective Head for Alugolla PSPP

The effective head is calculated on the basis of the following equation;

$$
\begin{aligned}
& H g=M W L-T W L=H W L-\frac{h a}{3}-T W L \\
& =804.3 m-289.1 \mathrm{~m}=515.2 \mathrm{~m} \\
& H l=a x L 1+b x L 2+c x L 3+\Delta h \quad= \\
& 1 / 300 \times 2350+1 / 100 \times 1320+1 / 300 \times 430+3.5=30 \mathrm{~m} \\
& H e=H g-H l \quad=515.2-30=485.2 \mathrm{~m} \\
& \text { where, }
\end{aligned}
$$

MWL: Normal intake water level $(\mathrm{m})=804.3 \mathrm{~m}$; TWL: Tailwater level $(\mathrm{m})=289.1 \mathrm{~m} ; \mathrm{Hg}$ : Gross head $(\mathrm{m})=515.2 \mathrm{~m} ; \mathrm{Hl}$ : Head loss $(\mathrm{m})=30 \mathrm{~m}$; He : Effective head $(\mathrm{m})=485.2 \mathrm{~m}$; L1 : Length of headrace $(\mathrm{m})=2350 \mathrm{~m}$;

L2: Length of penstock $(\mathrm{m})=1320 \mathrm{~m}$; L3 : Length of tailrace $(\mathrm{m})=430 \mathrm{~m} ; \Delta \mathrm{h}$ : Other head losses $(\mathrm{m})$ $=3.5 \mathrm{~m}$

\section{Re-Calculation of Maximum Plant Discharge- Uduwela PSPP \\ The normal effective head (Hes) $387.6 \mathrm{~m}$ is determined and the maximum plant discharge is then determined from the following equation;

$$
\begin{aligned}
& Q \max =\frac{P}{9.8 \times H x \eta} \quad=500,000 \mathrm{~kW} /(8.5 \times 387.6 \mathrm{~m})= \\
& 152 \mathrm{~m}^{3} / \mathrm{s}
\end{aligned}
$$

\section{Re-calculation of Maximum Plant Discharge- Alugolla PSPP}

The normal effective head (Hes) $485.2 \mathrm{~m}$ is determined and the maximum plant discharge is then determined from the following equation;

$$
\begin{aligned}
& Q \max =\frac{P}{9.8 \times H x \eta}=500,000 \mathrm{~kW} /(8.5 \times 485.2 \mathrm{~m}) \\
& =121 \mathrm{~m}^{3} / \mathrm{s}
\end{aligned}
$$

\section{Calculation of Annual Energy Generation- Uduwella PSSP}

The annual energy generation is obtained by the following equation.

$E=P \times T=500,000 \mathrm{~kW} \times 2190$ hours $=1,095 \mathrm{GWh}$ $\mathrm{kWh}$

\section{Calculation of Annual Energy Generation- Uduwella PSPP}

The annual energy generation is obtained by the following equation.

$E=P \times T=500,000 \mathrm{~kW} \times 2190$ hours $=1,095 \mathrm{GWh}$ Where, E: Annual energy generation (kWh); T: Annual generating hours (hrs)

\section{Calculation of Reservoir Volume-Uduwella PSPP}

$$
V e=Q \max x T \times 3600=152 \frac{m 3}{s} \times 6 \text { hrsx } 3600
$$

$$
=3,282,200 C M
$$


Calculation of Reservoir Volume-Alugolla PSPP

$$
\begin{gathered}
V e=Q \max x T x 3600=121 \frac{\mathrm{m} 3}{\mathrm{~s}} \times 6 \text { hrsx } 3600 \\
=2,613,600 \mathrm{CM}
\end{gathered}
$$

KMG Pumped Storage Power Plant Complex The project is to be situated on three streams namely Kuda Oya, Mul Oya and Gurugal Oya, in the Gampola area, No. 61, 1:50,000 map. The upper ponds are in Mul Oya and Gurugal Oya. All the three ponds are in Nuwara Eliya district, Central Province of the Sri Lanka. The principal features of the Project will be;

\begin{tabular}{|c|c|c|c|}
\hline & KMG PSPP COMPLEX & KM PSPP & KG PSPP \\
\hline \multirow{4}{*}{$\begin{array}{l}\text { Project } \\
\text { Specification }\end{array}$} & Installed Capacity P (MW) & 250 & 500 \\
\hline & Designed Discharge Q $\left(\mathrm{m}^{3} / \mathrm{s}\right)$ & 80.2 & 98.25 \\
\hline & Effective Head $\mathrm{H}_{\mathrm{e}}(\mathrm{m})$ & 366.7 & 598.7 \\
\hline & Peak Duration Hours & 6 & 6 \\
\hline \multirow[t]{7}{*}{ Upper Reservoir } & Dam Type & Concrete Gravity & Rock Fill \\
\hline & Dam Height (m) & 53 & 64 \\
\hline & Crest Length $(\mathrm{m})$ & 220 & 420 \\
\hline & Reservoir Volume at FSL ( Mil m³) & 1.732 & 2.122 \\
\hline & H.W.L (m) & 1,114 & 1,348 \\
\hline & L.W.L (m) & 1,086 & $1,305.8$ \\
\hline & Usable Water Depth (m) & 28 & 42.2 \\
\hline \multirow[t]{8}{*}{ Lower Reservoir } & Dam Type & \multicolumn{2}{|l|}{ Rock Fill } \\
\hline & Dam Height (m) & \multicolumn{2}{|l|}{24} \\
\hline & Crest Length $(\mathrm{m})$ & \multicolumn{2}{|l|}{260} \\
\hline & Reservoir Volume at FSL ( Mil m³) & \multicolumn{2}{|l|}{3.854} \\
\hline & H.W.L (m) & \multicolumn{2}{|l|}{708} \\
\hline & L.W.L (m) & \multicolumn{2}{|l|}{694.3} \\
\hline & Usable Water Depth (m) & \multicolumn{2}{|l|}{13.7} \\
\hline & Headrace $(\mathrm{m})$ & 1,120 & 3,280 \\
\hline \multirow[t]{2}{*}{ Water way } & Penstock (m) & 2,320 & 1,220 \\
\hline & Tail Race (m) & 1,260 & 1,560 \\
\hline Power House & Type & Underground & Underground \\
\hline \multicolumn{2}{|l|}{$\mathrm{L} / \mathrm{H}$} & 11.6 & 9.0 \\
\hline
\end{tabular}

Table 4 - Summery of Basic Design Configuration of KMG PSPP Complex

\section{Puna-Kotmale Pumped Storage Power Plant}

The project is to be situated on the Puna Oya and Kotmale Oya which are connected to
Kotmale Oya reservoir in the $\mathrm{N}^{\prime}$ Eliya district, Central Region of Sri Lanka. The principal features of the Project will be;

Table 5 - Summary of Basic Design Configuration of Puna-Kotmale PSPP

\begin{tabular}{|l|l|l|}
\hline \multicolumn{2}{|c|}{ Puna-Kotmale PSPP } \\
\hline Project & Installed Capacity $\mathrm{P}(\mathrm{MW})$ & 500 \\
\hline Specification & Designed Discharge $\mathrm{Q}\left(\mathrm{m}^{3} / \mathrm{s}\right)$ & 88 \\
\hline & Effective Head $\mathrm{H}_{\mathrm{e}}(\mathrm{m})$ & 666.5 \\
\hline & Peak Duration Hours & 6 \\
\hline Upper Reservoir & Dam Type & Concrete Gravity \\
\hline & Dam Height $(\mathrm{m})$ & 49 \\
\hline & Crest Length $(\mathrm{m})$ & 270 \\
\hline & Reservoir Volume at FSL $\left(\mathrm{Mil} \mathrm{m}^{3}\right)$ & 1.9 \\
\hline & H.W.L $(\mathrm{m})$ & 1,503 \\
\hline & L.W.L $(\mathrm{m})$ & $1,471.4$ \\
\hline & Usable Water Depth $(\mathrm{m})$ & 31.6 \\
\hline & Dam Type & Concrete Gravity \\
\hline & Dam Height $(\mathrm{m})$ & 57 \\
\hline & Crest Length $(\mathrm{m})$ & 220 \\
\hline & Reservoir Volume at FSL $($ Mil m 33$)$ & 1.9 \\
\hline & H.W.L $(\mathrm{m})$ & 790 \\
\hline & L.W.L $(\mathrm{m})$ & 775.4 \\
\hline Weservoir & Usable Water Depth $(\mathrm{m})$ & 14.6 \\
\hline & Headrace $(\mathrm{m})$ & 4,110 \\
\hline
\end{tabular}


SLEMA Journal, Volume 18, No. 2, September 2015

\begin{tabular}{|l|l|l|}
\hline & Penstock $(\mathrm{m})$ & 2,230 \\
\hline & Tail Race $(\mathrm{m})$ & 430 \\
\hline Power House & Type & Underground \\
\hline L/H & & 9.4 \\
\hline
\end{tabular}

\section{Dambagastalawa Pumped Storage Power Plant}

The project is to be situated on the Dambagastalawa Oya, near Ambewela, Pattipola fields in the Nuwara Eliya district, Central Region of the Sri Lanka. The principal features of the Project will be;

Table 6 - Summary of Basic Design Configuration of Dambagastalawa PSPP

\begin{tabular}{|c|c|c|}
\hline \multicolumn{3}{|c|}{ Dambagastalawa PSPP } \\
\hline \multirow{4}{*}{$\begin{array}{l}\text { Project } \\
\text { Specification }\end{array}$} & Installed Capacity P (MW) & 300 \\
\hline & Designed Discharge $\mathrm{Q}\left(\mathrm{m}^{3} / \mathrm{s}\right)$ & 79 \\
\hline & Effective Head $\mathrm{H}_{\mathrm{e}}(\mathrm{m})$ & 445.8 \\
\hline & Peak Duration Hours & 6 \\
\hline \multirow[t]{7}{*}{ Upper Reservoir } & Dam Type & Rock Fill \\
\hline & Dam Height (m) & 26 \\
\hline & Crest Length $(\mathrm{m})$ & 440 \\
\hline & Reservoir Volume at FSL (Mil m³) & 1.7 \\
\hline & H.W.L (m) & 1,831 \\
\hline & L.W.L (m) & 1,813 \\
\hline & Usable Water Depth (m) & 18 \\
\hline \multirow[t]{7}{*}{ Lower Reservoir } & Dam Type & Rock Fill \\
\hline & Dam Height $(\mathrm{m})$ & 28 \\
\hline & Crest Length $(\mathrm{m})$ & 280 \\
\hline & Reservoir Volume at FSL (Mil m³) & 1.7 \\
\hline & H.W.L (m) & 1,363 \\
\hline & L.W.L (m) & $1,351.5$ \\
\hline & Usable Water Depth $(\mathrm{m})$ & 11.5 \\
\hline \multirow[t]{3}{*}{ Water way } & Headrace $(\mathrm{m})$ & 1,760 \\
\hline & Penstock (m) & 850 \\
\hline & Tail Race $(\mathrm{m})$ & 690 \\
\hline Power House & Type & Underground \\
\hline \multicolumn{2}{|l|}{$\mathrm{L} / \mathrm{H}$} & 6.0 \\
\hline
\end{tabular}

\section{Agra Pumped Storage Power Plant}

The project is to be situated on the Agra Oya, near Pattipola field in the Nuwara Eliya district, The principal features of the Project will be; Central Region of the Sri Lanka.

Table 7 - Summary of Basic Design Configuration of Agra PSPP

\begin{tabular}{|c|c|c|}
\hline \multicolumn{3}{|l|}{ AGRA PSPP } \\
\hline Project & Installed Capacity P (MW) & 300 \\
\hline \multirow[t]{3}{*}{ Specification } & Designed Discharge $\mathrm{Q}\left(\mathrm{m}^{3} / \mathrm{s}\right)$ & 86.9 \\
\hline & Effective Head $\mathrm{H}_{\mathrm{e}}(\mathrm{m})$ & 406 \\
\hline & Peak Duration Hours & 6 \\
\hline \multirow[t]{7}{*}{ Upper Reservoir } & Dam Type & Rock Fill \\
\hline & Dam Height (m) & 22 \\
\hline & Crest Length $(\mathrm{m})$ & 440 \\
\hline & Reservoir Volume at FSL ( Mil m3) & 1.9 \\
\hline & H.W.L (m) & 1,827 \\
\hline & L.W.L (m) & $1,813.2$ \\
\hline & Usable Water Depth (m) & 13.8 \\
\hline \multirow[t]{5}{*}{ Lower Reservoir } & Dam Type & Rock Fill \\
\hline & Dam Height (m) & 36 \\
\hline & Crest Length $(\mathrm{m})$ & 250 \\
\hline & Reservoir Volume at FSL ( Mil m3) & 1.9 \\
\hline & H.W.L (m) & 1,401 \\
\hline
\end{tabular}




\begin{tabular}{|l|l|l|}
\hline & L.W.L $(\mathrm{m})$ & $1,389.2$ \\
\hline & Usable Water Depth $(\mathrm{m})$ & 11.8 \\
\hline Water way & Headrace $(\mathrm{m})$ & 120 \\
\hline & Penstock $(\mathrm{m})$ & 630 \\
\hline & Tail Race $(\mathrm{m})$ & 2,730 \\
\hline Power House & Type & Underground \\
\hline L/H & 11.0 \\
\hline
\end{tabular}

\section{Conclusion}

The nature has blessed with several natural locations which are suitable for developing Pumped Storage Power Plants. A few sites can be developed as Pumped Storage Power Plant Complexes which further improves their economic viability.

The calculated basic project design parameters will be used to calculate the cost of the particular project in pre-feasibility level. Thereby, these basic design parameters will be used for the detailed design work of the best selected candidate sites.

The summary of the basic design parameter of the sites which were considered in this paper are given in the Table 8.

Note: This paper was presented in the Energy Symposium Sri Lanka 2015.

Table 8 - The Summary of the Basic Design Configuration of the Sites

\begin{tabular}{|c|c|c|c|c|c|c|c|c|}
\hline \multirow{6}{*}{$\begin{array}{l}\text { Project } \\
\text { Specification }\end{array}$} & \multirow[b]{2}{*}{$\begin{array}{l}\text { Design } \\
\text { Configurations }\end{array}$} & \multicolumn{2}{|c|}{ MAHA PSPPC } & \multicolumn{2}{|c|}{ KMG PSPPC } & \multirow{2}{*}{$\begin{array}{l}\text { Puna- } \\
\text { Kothmale } \\
\text { PSPP }\end{array}$} & \multirow{2}{*}{$\begin{array}{c}\text { Dambag } \\
\text { astalawa } \\
\text { PSPP }\end{array}$} & \multirow[b]{2}{*}{$\begin{array}{l}\text { Agra } \\
\text { PSPP }\end{array}$} \\
\hline & & $\begin{array}{l}\text { Uduwella } \\
\text { PSPP }\end{array}$ & $\begin{array}{l}\text { Alugoll } \\
\text { a PSPP }\end{array}$ & $\begin{array}{c}\text { KM } \\
\text { PSPP }\end{array}$ & KG PSPP & & & \\
\hline & Installed & 500 & 500 & 250 & 500 & 500 & 300 & 300 \\
\hline & Design & 152 & 121 & 80.2 & 98.25 & 88 & 79 & 86.9 \\
\hline & Effective head & 387.6 & 485.2 & 366.7 & 598.7 & 666.5 & 445.8 & 406 \\
\hline & Peak Duration & 6 & 6 & 6 & 6 & 6 & 6 & 6 \\
\hline \multirow{7}{*}{$\begin{array}{l}\text { Upper } \\
\text { Reservoir }\end{array}$} & Dam Type & Rock fill & Conc. & Conc. & Rock fill & Conc. & Rock fill & Rock fill \\
\hline & Dam Height & 32 & 41 & 53 & 64 & 49 & 26 & 22 \\
\hline & Crest Length & 340 & 260 & 220 & 420 & 270 & 440 & 440 \\
\hline & Reservoir & 3.38 & 2.6 & 1.732 & 2.122 & 1.9 & 1.7 & 1.9 \\
\hline & $\mathrm{HW}(\mathrm{m})$ & 714 & 814 & 1,114 & 1,348 & 1,503 & 1,831 & 1,827 \\
\hline & LWL (m) & 694.45 & 785 & 1,086 & $1,305.8$ & $1,471.4$ & 1,813 & $1,813.2$ \\
\hline & Usable Water & 19.55 & 29 & 28 & 42.2 & 31.6 & 18 & 13.8 \\
\hline \multirow{7}{*}{$\begin{array}{l}\text { Lower } \\
\text { Reservoir }\end{array}$} & Dam Type & \multicolumn{2}{|c|}{ Concrete Gravity } & \multicolumn{2}{|c|}{ Rock fill } & Conc. & Rock fill & Rock fill \\
\hline & Dam Height (m) & \multicolumn{2}{|c|}{57} & \multicolumn{2}{|c|}{24} & 57 & 28 & 36 \\
\hline & Crest Length & \multicolumn{2}{|c|}{350} & \multicolumn{2}{|c|}{260} & 220 & 280 & 250 \\
\hline & Reservoir & \multicolumn{2}{|c|}{5.94} & \multicolumn{2}{|c|}{3.854} & 1.9 & 1.7 & 1.9 \\
\hline & HWL (m) & \multicolumn{2}{|c|}{300} & \multicolumn{2}{|c|}{708} & 790 & 1363 & 1401 \\
\hline & LWL (m) & \multicolumn{2}{|c|}{267.2} & \multicolumn{2}{|c|}{694.3} & 775.4 & $1,351.5$ & $1,389.2$ \\
\hline & Usable Water & \multicolumn{2}{|c|}{32.8} & \multicolumn{2}{|c|}{13.7} & 14.6 & 11.5 & 11.8 \\
\hline \multirow{3}{*}{ Water way } & Headrace $(\mathrm{m})$ & 1,850 & 2,350 & 1,120 & 3,280 & 4,110 & 1,760 & 120 \\
\hline & Penstock (m) & 2,400 & 1,320 & 2,320 & 1,220 & 2,230 & 850 & 630 \\
\hline & Tail Race (m) & 200 & 430 & 1,260 & 1,560 & 430 & 690 & 2,730 \\
\hline \multicolumn{2}{|l|}{$\mathrm{L} / \mathrm{H}$} & 10.64 & 7.86 & 11.6 & 9 & 9.4 & 6 & 11 \\
\hline \multicolumn{2}{|c|}{ Power House Type } & $\begin{array}{l}\text { Undergro } \\
\text { und }\end{array}$ & $\begin{array}{l}\text { Undergr } \\
\text { ound }\end{array}$ & $\begin{array}{l}\text { Undergr } \\
\text { ound }\end{array}$ & $\begin{array}{l}\text { Undergr } \\
\text { ound }\end{array}$ & $\begin{array}{c}\text { Undergrou } \\
\text { nd }\end{array}$ & $\begin{array}{l}\text { Undergr } \\
\text { ound }\end{array}$ & $\begin{array}{l}\text { Undergr } \\
\text { ound }\end{array}$ \\
\hline \multicolumn{2}{|c|}{ Construction Period } & 6 & 6 & 6 & 6 & 6 & 6 & 6 \\
\hline \multicolumn{2}{|c|}{ Average Rainfall (mm) } & 1,450 & 1,450 & 1,450 & 1,450 & 1,450 & 1,450 & 1,450 \\
\hline
\end{tabular}

\section{References}

1. Guide manual for Development Aid Programs and Studies of Hydro Electric Power Projects, New Energy Foundation, Tokyo, Japan 1996.
2. Planning of Pumped Storage Power Plants in Sri Lanka, M.T.A.P. Wickramarathna, SLEMA Journal, Volume 14-No.2, September 2011. 